\title{
Contribution to a bio-optical model for remote sensing of Lena River water
}

\author{
H. Örek ${ }^{1}$, R. Doerffer ${ }^{1}$, R. Röttgers ${ }^{1}$, M. Boersma ${ }^{2}$, and K. H. Wiltshire ${ }^{2}$ \\ ${ }^{1}$ Helmholtz-Zentrum Geesthacht, Centre for Materials and Research, Institute for Coastal Research, Max-Planck-Str. 1., \\ 21502 Geesthacht, Germany \\ ${ }^{2}$ Alfred Wegener Institute, Helmholtz Centre for Polar and Marine Research, Biologische Anstalt Helgoland, P.O. Box 180, \\ 27483 Helgoland, Germany
}

Correspondence to: R. Röttgers (ruediger.roettgers@hzg.de)

Received: 18 January 2013 - Published in Biogeosciences Discuss.: 11 March 2013

Revised: 2 September 2013 - Accepted: 16 September 2013 - Published: 8 November 2013

\begin{abstract}
Bio-optical measurements and sampling were carried out in the delta of the Lena River (northern Siberia, Russia) between 26 June and 4 July 2011. The aim of this study was to determine the inherent optical properties of the Lena water, i.e., absorption, attenuation, and scattering coefficients, during the period of maximum runoff. This aimed to contribute to the development of a biooptical model for use as the basis for optical remote sensing of coastal water of the Arctic. In this context the absorption by CDOM (colored dissolved organic matter) and particles, and the concentrations of total suspended matter, phytoplankton-pigments, and carbon were measured. CDOM was found to be the most dominant parameter affecting the optical properties of the river, with an absorption coefficient of $4.5-5 \mathrm{~m}^{-1}$ at $442 \mathrm{~nm}$, which was almost four times higher than total particle absorption values at visible wavelength range. The wavelenght-dependence of absorption of the different water constituents was chracterized by determining the semi logarithmic spectral slope. Mean CDOM, and detritus slopes were $0.0149 \mathrm{~nm}^{-1}$ (standard deviation $($ stdev $)=0.0003, n=18)$, and $0.0057 \mathrm{~nm}^{-1}(\operatorname{stdev}=0.0017$, $n=19$ ), respectively, values which are typical for water bodies with high concentrations of dissolved and particulate carbon. Mean chlorophyll $a$ and total suspended matter were $1.8 \mathrm{mg} \mathrm{m}^{-3}$ (stdev $\left.=0.734 n=18\right)$ and $31.9 \mathrm{~g} \mathrm{~m}^{-3}$ ( $\operatorname{stdev}=19.94, n=27)$, respectively. DOC (dissolved organic carbon) was in the range $8-10 \mathrm{~g} \mathrm{~m}^{-3}$ and the total particulate carbon (PC) in the range $0.25-1.5 \mathrm{~g} \mathrm{~m}^{-3}$. The light penetration depth (Secchi disc depth) was in the range 30$90 \mathrm{~cm}$ and was highly correlated with the suspended matter
\end{abstract}

concentration. The period of maximum river runoff in June was chosen to obtain bio-optical data when maximum water constituents are transported into the Laptev Sea. However, we are aware that more data from other seasons and other years need to be collected to establish a general bio-optical model of the Lena water and conclusively characterize the light climate with respect to primary production.

\section{Introduction}

The Lena River with its extensive delta is the pathway for transport of large amounts of organic and inorganic material, in diverse forms of carbon, from its huge catchment area of about $2486000 \mathrm{~km}^{2}$ into the Arctic Ocean, particularly into the Laptev Sea (Kattner et al., 1999). It has an annual fresh water discharge of around $500 \mathrm{~km}^{3}$ (Dmitrenko et al., 2008; http://www.feow.org/ecoregion_details.php?eco= 608). Of all major arctic rivers it dominates the supply of the Arctic Ocean with dissolved organic carbon, DOC, and colored dissolved organic matter, CDOM (Stedmon et al., 2011; http://www.arcticgreatrivers.org/index.html). Permafrost thawing and diminishing sea ice coverage are distinctive indicators of global warming in the Arctic (Walsh, 1991; Payette et al., 2004; Morison et al., 2012) and the input of carbon may increase with the thawing of Siberian permafrost due to global warming. Changes in hydrographic and meteorological conditions have been observed in the Lena Delta, which in turn influence the Arctic Ocean (Morison et al., 2012). Considerable water budget, geomorphological 
and ecosystem changes are expected in the near future (McClelland et al., 2006; Dmitrenko et al., 2008; Morison et al., 2012). Currently, however, it is not so easy to predict the future of the Lena Delta and its output with the current lack of present, past and perhaps most importantly continuous measurement data. Gathering of relevant data is not always possible by in situ sampling in such inaccessible areas like the Lena Delta. Here remote sensing tools can be useful and contribute to the understanding of the current riverine conditions and facilitate a continuous monitoring program. Nevertheless, as the basis for optical remote sensing of water is the knowledge of its optical properties, it is imperative that the relationship between these and the concentrations of the water constituents is measured in situ. Such optical data, apart from underpinning remote sensing studies, are important for determining primary production.

Previous studies of optical properties in the Lena Delta region are mainly focused on the characterization and quantification of CDOM, POM (particulate organic matter), phytoplankton distribution, and primary production (Cauwet and Sidorov, 1996; Heiskanen and Keck, 1996; Sorokin and Sorokin, 1996; Kattner et al., 1999; Gueguen et al., 2005). Investigations in the Laptev Sea were mostly limited to the marine areas, and did not include the Lena River itself or its shallow coastal region of freshwater influence. Thus, the Lena River ecosystem is not well documented in terms of bio-optical properties.

According to these limited previous studies, the carbon budget of the Lena River varies a great deal. During the flood period TOC (total organic carbon) can be up to $14.4 \mathrm{~g} \mathrm{~m}^{-3}$ (June-July), while during the low water level period (November-April) this value is reported to be around $4 \mathrm{~g} \mathrm{~m}^{-3}$, and the annual mean concentration is $10.2 \mathrm{~g} \mathrm{~m}^{-3}$ (Cauwet and Sidorov, 1996). Along the river the TOC concentration remains almost constant from Yakutsk $(2000 \mathrm{~km}$ upstream) to the Laptev Sea (Lara et al., 1998). Turbidity of the water is higher during the flood period with concentrations of suspended matter dry weight of $50-70 \mathrm{~g} \mathrm{~m}^{-3}$. The concentration of phosphate was found to be similar to other Arctic rivers but silicate and nitrate are three times higher (Cauwet and Sidorov, 1996).

The phytoplankton community of the Lena River is dominated by fresh water diatoms and picocyanobacteria (Heiskanen and Keck, 1996; Sorokin and Sorokin, 1996). Reported wet weights of the dominant groups and size-fractionated chlorophyll concentrations are given below (Table 1).

Bio-optical data of the Lena River are scarce. In some studies Secchi disk depths and light attenuation coefficients were measured or calculated (Sorokin and Sorokin, 1996). The DOM (dissolved organic matter) composition in the Lena is well documented (Lara et al., 1998; Kattner et al., 1999; Lobbes et al., 2000). Particulate matter of the Lena River is composed of a lithogenic fraction, which stems from erosion by the river, and of detritus, which is formed mainly by the debris of organisms. Phytoplankton contributes only a
Table 1. Summary of the phytoplankton composition, size fraction, and total production in the Lena River.

\begin{tabular}{lccc}
\hline & $\begin{array}{c}\text { Picocyano- } \\
\text { bacteria } \\
<3 \mu \mathrm{m}\end{array}$ & $\begin{array}{c}\text { Nanophyto- } \\
\text { plankton } \\
3-10 \mu \mathrm{m}\end{array}$ & $\begin{array}{c}\text { larger } \\
\text { microalgae } \\
>10 \mu \mathrm{m}\end{array}$ \\
\hline${ }^{1}$ Fraction of Chl $a$ in Lena & 0.07 & 0.16 & 0.77 \\
${ }^{1}$ Fraction of phae in Lena & 0.16 & 0.21 & 0.63 \\
${ }^{2}$ Wet weight $\mathrm{mg} \mathrm{m}^{-3}$ & 19 & 36 & 407 \\
${ }^{2}$ Prim. prod. $\mathrm{mg} \mathrm{C} \mathrm{m}^{-3}$ day $^{-1}$ & & $50-126$ & \\
${ }^{1}$ Chl $a$ concentration $\mathrm{mg} \mathrm{m}^{-1}$ & & $1.5-4.5$ & \\
\hline
\end{tabular}

${ }^{1}$ Heiskanen and Keck (1996),

2 Sorokin and Sorokin (1996)

few percent to the total particulate matter. The main sources of total suspended matter (TSM) are eroded land and the thawing permafrost (Rachold et al., 1996; Lobbes et al., 2000).

Similar studies in the Kara Sea about optical properties, remote sensing, and carbon content were carried out by Pozdnyakov et al. (2005), Hessen et al. (2010), and Korosov et al. (2011).

The goal of our study was to determine the optical properties of the Lena River water during the period of maximum river runoff, i.e., when most of the annual water load is transported into the Laptev Sea. The intention was to set up a preliminary bio-optical model, which describes the dominant components and which determines the optical properties, the ranges of their concentrations, their absorption and scattering spectra, and the relationships between concentrations and the optical coefficients. A bio-optical model is the basis for optical remote sensing and light climate related phytoplankton studies.

The selected investigation site was at the entrance of the Lena Delta, where the river water is divided up into different channels and flows via many arms into the coastal sea. The period and site of our investigation was selected to match the maximum concentrations of water constituents before they diffuse into the coastal sea. Unfortunately, the maximum water level was earlier in 2011 than predicted, so that we missed the extreme phase by 7-10 days, but which on the other hand allowed us to study both the end of the high-water period as well as the beginning of the summer period, thus yielding information for different situations.

\section{Investigation site and methods}

All measurements were carried out in the vicinity of Samoylov Island, which is located at the entrance of the delta (Fig. 1). Daily water samples were collected from the Lena River two times a day. The first sampling point was located at the Samoylov Island coast (Station 2 in Fig. 1 and Table 2), and the second sampling location (Station 1 in Fig. 1 and Table 2) was in the main stream of the Lena, close to the small rock island of Stolp. Samples were taken from a small boat. 


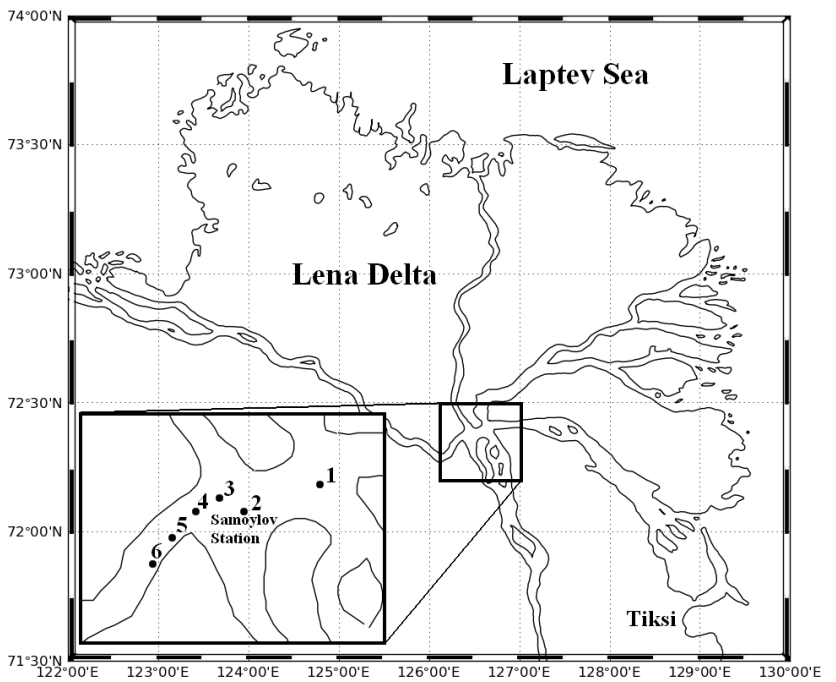

Fig. 1. Study area and location of sampling stations.

In addition to these positions another branch of the Lena River was sampled once (Stations 3-6 in Fig. 1 and Table 2). Samples were taken usually between 10:30 and 15:30 local time when the sun elevation was relatively high and overpasses of the ENVISAT satellite were expected. At the time of sampling we measured water and air temperatures, Secchi disk depths, reflectance spectra, phytoplankton fluorescence profiles, and GPS coordinates (Table 2).

Measurements of the in vivo fluorescence profiles were carried out with the Fluoroprobe Algae Analyser (BBE Moldaenke, Kiel, Germany, www.bbe-moldaenke.de). This instrument allows the differentiation of algal groups by using the different fluorescent spectra of them (Beutler et al., 2002).

All samples were processed at the Samoylov research station. Filters were prepared for measuring particle absorption, total suspended matter dry weight, and phytoplankton pigment concentrations by HPLC later in the home laboratory. Between 200 and $1500 \mathrm{~mL}$ of the water samples was filtered through pre-combusted GF/F filters and kept in a deep freezer $\left(-18^{\circ} \mathrm{C}\right)$ until transfer in the freezer to Germany. These samples were analyzed as soon as received from Siberia 6-7 months later, to prevent or reduce further degradation of the biological material.

The absorption and scattering spectra of the fresh samples were measured before and after filtration at Samoylov using a Wetlabs hyperspectral absorption-attenuation meter (AC$\mathrm{S})$. Using these measurements the absorption and scattering coefficients of particulate matter and the dissolved fraction (CDOM) could be determined.

\section{Measurements and post processing}

The ACS is designed for in situ measurements. It has two different cuvettes, one for measuring the beam attenuation coefficient $c$ and the other for measuring the absorption coefficient $a$. To measure the samples at the station the instrument was installed in the lab and fixed upright to the bench leg. Silicon tubings were attached to the inlets of the cuvettes and the samples were poured from the lower inlet to avoid or minimize bubbles (schematic setup can be found in Sullivan et al., 2006). The absorption and beam attenuation spectra were recorded. Three replicates were measured for each sample together with a blank, which was recorded between the individual measurements to check the stability of the instrument. Temperature and scattering corrections were done by post processing of the raw data (Zaneveld et al., 1994; Sullivan et al., 2006; Boss et al., 2009). Blank values were not used for the calculations, because it was not possible to produce or store optically clean water at the station; instead previous blank values - measured before the campaign - were used for post processing of the raw data. However, this step was not critical, since blanks are less important for such highly absorbing water bodies.

The spectral shape of total absorption and that of the filtered water, which represents CDOM, were parameterized by fitting an exponential curve to the measured spectrum for the wavelength range $400-500 \mathrm{~nm}$, which is the most important range for optical remote sensing of CDOM. This method was introduced by Jerlov in 1957. The spectral slope of the semilogarithmic CDOM curve is variable and depends on the kind of matter being measured. Thus, the exponent $s$, which is the spectral slope on a semi-logarithmic plot, is an important parameter for the characterization of CDOM. The absorption at other wavelengths can then be computed using (Eq. 1):

$a(\lambda)=a\left(\lambda_{0}\right) \exp \left\{-s\left(\lambda-\lambda_{0}\right)\right\}$

where $a$ is absorption, $\lambda$ is wavelength, $\lambda_{0}$ is the reference wavelength, and $s$ is the spectral slope.

At each station the Secchi disc depth (SD) was determined. Due to the low transparency of Lena water and the high current speed a standard device with a marked cable could not be used. Instead a white disc was mounted at the tip of a pole of $2 \mathrm{~m}$ length, which was marked with a centimeter scale. This pole was deployed from the boat by hand.

The absorption of particulate matter was measured using the filter pad technique, which is a standard method to determine the absorption spectra of total suspended matter, detritus and phytoplankton (details in Mitchell et al., 2000). The main difficulty with the filter pad technique is the aggregating of particles in a small cross section, reasoning an artificial amplification of absorption. This amplification is corrected by an amplification factor. In this study we used the method of measurement and correction described in Röttgers and Gehnke (2012). Measurements were made in a dual-beam UV/VIS spectrophotometer (Lambda 950, Perkin Elmer) that 
Table 2. Sampling protocol, complementary data, and filtered volume of the collected samples. (Station locations can be found in Fig. 1). n.a.: not available.

\begin{tabular}{|c|c|c|c|c|c|c|c|c|c|c|}
\hline \multicolumn{5}{|c|}{ Location, Time and Station Information } & \multicolumn{3}{|c|}{ Complementary Data } & \multicolumn{3}{|c|}{ Filtered Volumes (mL) } \\
\hline Date & Time (local) & Latitude & Longitude & Station Number & Secchi $(\mathrm{cm})$ & Water Temp & Air Temp & TSM & HPLC & PABS \\
\hline 26 Jun 2011 & 10:00:00 & 72.37 & 126.48 & 2 & 70 & n.a. & n.a. & 500 & 750 & 550 \\
\hline 26 Jun 2011 & $15: 35: 00$ & 72.39 & 126.64 & 1 & 75 & n.a. & n.a. & 1000 & n.a. & 1000 \\
\hline 27 Jun 2011 & 10:30:00 & 72.37 & 126.48 & 2 & 70 & 13 & & 1000 & 1000 & 1000 \\
\hline 27 Jun 2011 & 15:30:00 & 72.39 & 126.64 & 1 & 60 & 13.2 & 7.5 & 1000 & 1000 & 1000 \\
\hline 28 Jun 2011 & 10:50:00 & 72.33 & 126.29 & 6 & 80 & 12.5 & 8.2 & 1000 & 1000 & 500 \\
\hline 28 Jun 2011 & 11:20:00 & 72.35 & 126.33 & 5 & 85 & 12.3 & 9.5 & 1000 & 1000 & 500 \\
\hline 28 Jun 2011 & 11:53:00 & 72.37 & 126.38 & 4 & 80 & 12.2 & 8.4 & 1000 & 1000 & 500 \\
\hline 28 Jun 2011 & 12:10:00 & 72.38 & 126.43 & 3 & 75 & 12.2 & 8.6 & 1000 & 1000 & 500 \\
\hline 29 Jun 2011 & $10: 30: 00$ & 72.37 & 126.48 & 2 & 75 & 13.5 & 8.8 & 1500 & n.a. & n.a. \\
\hline 29 Jun 2011 & $15: 30: 00$ & 72.39 & 126.66 & 1 & 70 & 13.6 & 8.9 & 1500 & 1500 & 500 \\
\hline 30 Jun 2011 & 10:30:00 & 72.37 & 126.48 & 2 & n.a. & n.a. & n.a. & 1500 & 1500 & 500 \\
\hline 30 Jun 2011 & $15: 30: 00$ & 72.39 & 126.64 & 1 & n.a. & n.a. & n.a. & 1500 & 1000 & 500 \\
\hline 1 Jul 2011 & $10: 30: 00$ & 72.37 & 126.48 & 2 & 70 & 13.4 & 7.3 & 1500 & 1000 & 500 \\
\hline $1 \mathrm{Jul} 2011$ & 16:00:00 & 72.39 & 126.64 & 1 & 70 & 13 & 8.5 & 1500 & 1500 & 500 \\
\hline 2 Jul 2011 & 10:30:00 & 72.37 & 126.48 & 2 & 70 & 13.3 & 8.4 & 1500 & 1000 & 500 \\
\hline 2 Jul 2011 & $15: 50: 00$ & 72.39 & 126.66 & 1 & 50 & 13.3 & 12 & 1000 & 1000 & 250 \\
\hline 3 Jul 2011 & 19:30:00 & 72.37 & 126.46 & 2 & 35 & 13.7 & 17.8 & 700 & 700 & 200 \\
\hline 3 Jul 2011 & 20:00:00 & 72.39 & 126.66 & 1 & 30 & 13.8 & 16 & 700 & 700 & 200 \\
\hline 4 Jul 2011 & 09:00:00 & 72.37 & 126.47 & 2 & 40 & 14 & 18 & 1000 & 1000 & 250 \\
\hline 4 Jul 2011 & $15: 30: 00$ & 72.39 & 126.66 & 1 & 30 & 14.2 & 17.9 & 700 & 700 & 200 \\
\hline
\end{tabular}

was equipped with a $150 \mathrm{~mm}$ integrating sphere (Labsphere Inc.). A piece of filter $\left(\sim 1 \times 2 \mathrm{~cm}^{2}\right)$ was cut out and placed in the middle of the integrating sphere. The filter was defrosted for 30-45 min before measurement. Measured filter pieces were then bleached for several minutes by sodium hyperoxide to destroy the phytoplankton pigments. Blanks were treated with the same procedure. The absorption by detritus, also called non-algal particulate matter, are determined from the bleached filters directly, while the difference between untreated and bleached filters provides the absorption spectra of phytoplankton pigments. The absorption spectra resembled the CDOM curves and were analyzed in the same way. The wavelength exponent of the absorption spectra of detritus was computed in the same way as CDOM by fitting an exponential curve to the measured spectrum with the same reference wavelength of $442 \mathrm{~nm}$.

Samples for total particulate carbon (PC), which is the sum of inorganic (PIC) and organic (POC) particulate carbon, were taken daily by filtering $500-1000 \mathrm{~mL}$ of water onto pre-combusted and washed Whatman GF/F filters. The carbon content of the samples was measured with an Elementar Vario MICRO cube CHN analyser (Elementar Analysensysteme, www.elementar.de).

DOC was analyzed in the filtrates of the samples. The filtrate was acidified by the addition of $100 \mu \mathrm{L}$ of $\mathrm{HCl}(25 \%)$ before being sealed and stored in a dark fridge at $4{ }^{\circ} \mathrm{C}$ until analysis (Elementar Analysensysteme Vario TOC cube; www.elementar.de). All glassware used in the preparation of the DOC sample were previously washed in $10 \% \mathrm{HCl}$ and rinsed with ultrapure water (Milli-Q Integral Water Purification System, Millipore).

The wavelength dependent total scattering coefficients $b$ were obtained by subtracting total absorption ( $a$ of $\mathrm{CDOM}+$ water + particles) from the beam attenuation $c$ with $b=c-a$ where $c$ is the beam attenuation coefficient, $a$ is the absorption and $b$ is the scattering coefficient. By using $b$ of particles only, the single scatter albedo $\omega_{0}=b / c$ can be calculated, which provides information about the nature of particles. A high $\omega_{0}$ indicates inorganic suspended matter with a relatively low absorption coefficient.

Phytoplankton pigments were determined using HPLC (high performance liquid chromatography) and the method developed by Zapata et al. (2000). A total of 29 different pigments, including chlorophyll and degradation products, could be separated from the Lena samples. Pigment concentrations were computed from the area of the concentration peaks relative to pigment standards (DHI and Sigma). Filters were extracted for $24 \mathrm{~h}$ at $-40^{\circ} \mathrm{C}$ with $100 \%$ acetone (chromatography grade), then filtered through Whatman Spartan filters $(13 \mathrm{~mm} \varnothing, 0.2 \mu \mathrm{m}$ pore size) and transferred to the vials for chromatography.

TSM dry weight was determined by filtering the sampled water through pre-combusted $\left(450^{\circ} \mathrm{C}\right)$ and pre-weighted GF/F filters (Whatman). The nominal pore size of $0.7 \mu \mathrm{m}$ of these filters defines the separation of dissolved and particulate matter for this study. Before weighting the filters were dried at $60^{\circ} \mathrm{C}$ for $24 \mathrm{~h}$ and cooled to room temperature in a desiccator to prevent any change in weight due to humidity. The difference between the pre- and post-filter weights 


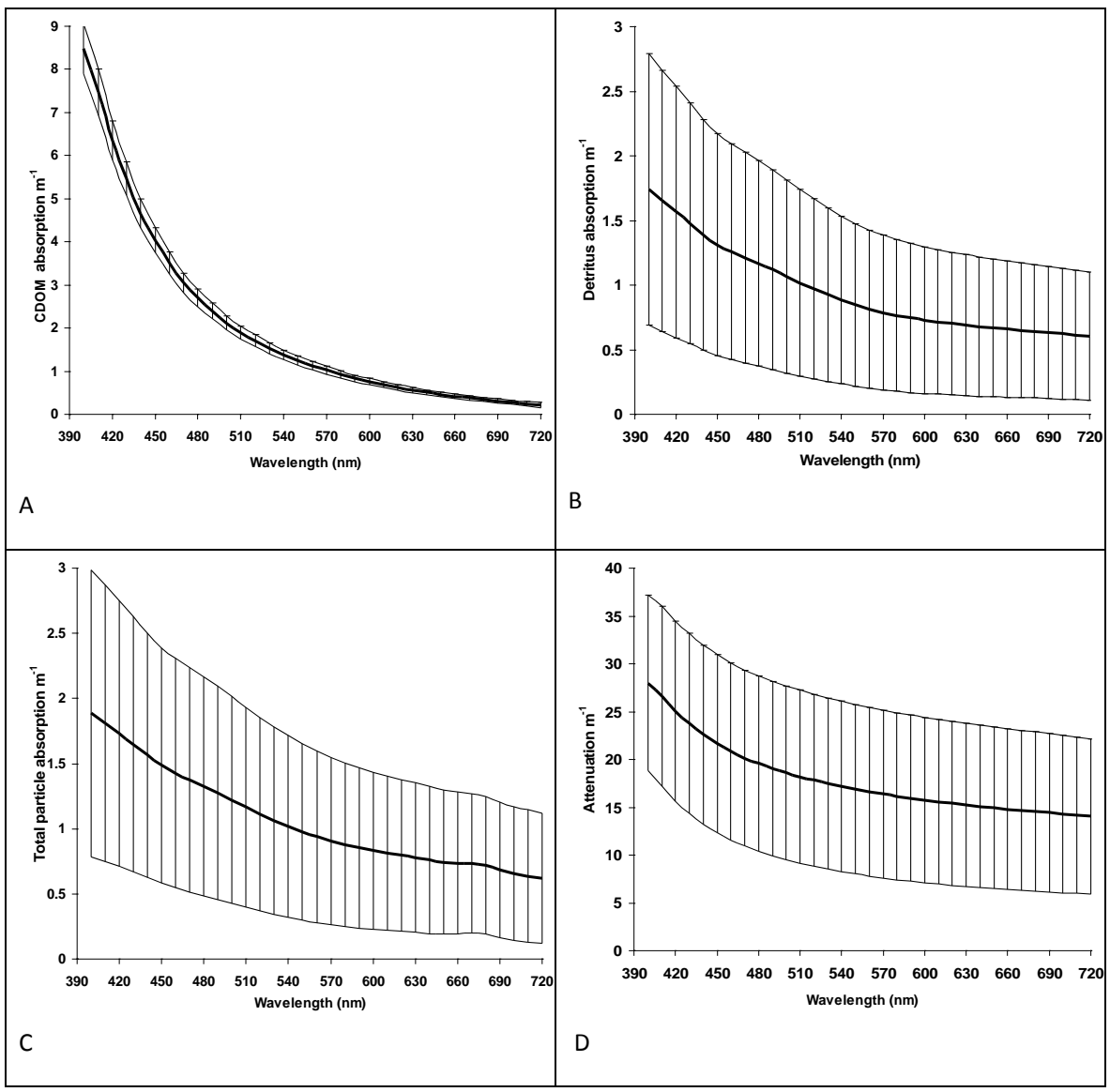

Fig. 2. Mean and standard deviations of the absorption coefficients of (A) CDOM, (B) particulate detritus, and (C) total particulate matter, and (D) of the beam attenuation of the samples.

divided by filtered sample volume is the dry weight of suspended matter per unit water volume.

\section{Results}

\subsection{Absorption}

Of all water constituents CDOM is the main source of absorption in the visible wavelength range in the Lena River. During the first week of our campaign CDOM absorption was almost uniform within the sampling area (Fig. 2a). At $442 \mathrm{~nm}$ it was in the range $4.25-5.25 \mathrm{~m}^{-1}$, with a standard deviation of $\pm 0.36 \mathrm{~m}^{-1}$. The decrease over time (Fig. 3) is not significant. Contrary to this slight decrease, an increase of the spectral slope was found (Fig. 4, Table 3). It varied between 0.0142 and $0.0158 \mathrm{~nm}^{-1}$ with a standard deviation of $\pm 0.0003 \mathrm{~nm}^{-1}$.

The absorption coefficients of TSM and of the detrital fraction (after bleaching) are very close to each other (Fig. $2 \mathrm{c}$ and $\mathrm{b}$, respectively). Thus, the difference between both, which is assumed to be the absorption by phytoplankton pigments, is low and noisy and thus not represented here. This is ex-

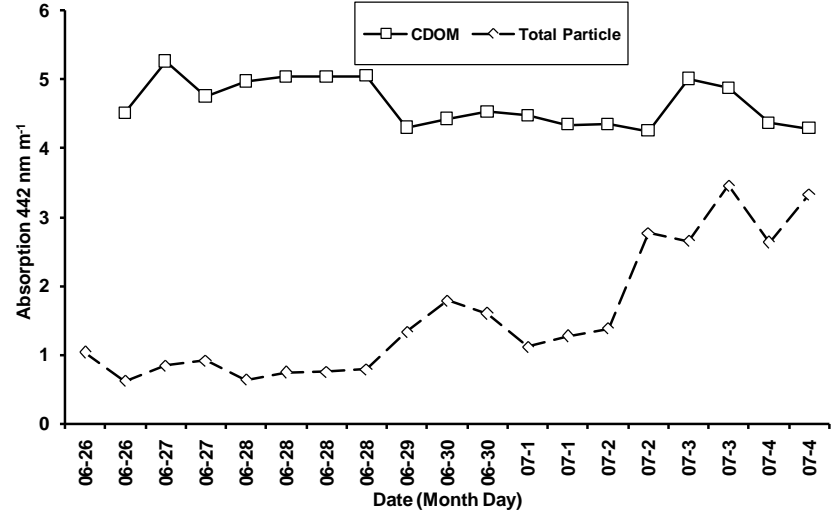

Fig. 3. CDOM and total particle absorption variability at $442 \mathrm{~nm}$ during the sampling period.

acerbated by the fact that the bleaching process does not only eliminate the absorption by pigments, but also partly of other organic matter. Another way to determine the absorption by chlorophyll is to calculate the difference between the absorption maximum of chlorophyll at 676 and $710 \mathrm{~nm}$ to 
Table 3. Slopes of CDOM and detritus absorption and concentrations of total suspended matter mg L ${ }^{-1}$, and chlorophyll $a \mu g \mathrm{~L}^{-1}$ (including all degradation products). Given below are the overall means and standard deviations.

\begin{tabular}{cccccc}
\hline Date & Time (local) & CDOM & Detritus & TSM & Chl_ $a^{*}$ \\
\hline 26 Jun 2011 & $10: 00: 00$ & No Data & 0.00622 & 15.06 & 0.920 \\
26 Jun 2011 & $15: 35: 00$ & 0.014323 & 0.006039 & 21.66 & No Data \\
26 Jun 2011 & $10: 30: 00$ & 0.014676 & 0.00527 & 19.51 & 2.184 \\
27 Jun 2011 & $15: 30: 00$ & 0.014781 & 0.004893 & 30.42 & 2.100 \\
28 Jun 2011 & $10: 00: 00$ & No Data & No Data & 15.43 & No Data \\
28 Jun 2011 & $10: 50: 00$ & 0.014859 & 0.008914 & 7.92 & 0.939 \\
28 Jun 2011 & $11: 20: 00$ & 0.014801 & 0.008649 & 9.36 & 1.610 \\
28 Jun 2011 & $11: 53: 00$ & 0.014711 & 0.00866 & 9.08 & 0.315 \\
28 Jun 2011 & $12: 10: 00$ & 0.014816 & 0.008331 & 8.45 & 2.306 \\
29 Jun 2011 & $10: 30: 00$ & No Data & No Data & 24.27 & No Data \\
29 Jun 2011 & $15: 30: 00$ & 0.014849 & 0.005714 & 27.25 & 2.043 \\
30 Jun 2011 & $10: 30: 00$ & 0.015026 & 0.004277 & 52.94 & 2.904 \\
30 Jun 2011 & $15: 30: 00$ & 0.014944 & 0.004771 & 37.34 & 2.995 \\
1 Jul 2011 & $10: 30: 00$ & 0.014958 & 0.005967 & 25.87 & 2.902 \\
1 Jul 2011 & $16: 00: 00$ & 0.015219 & 0.005387 & 28.63 & 1.930 \\
2 Jul 2011 & $10: 30: 00$ & 0.015159 & 0.005364 & 25.95 & 2.215 \\
2 Jul 2011 & $15: 50: 00$ & 0.015241 & 0.004244 & 54.77 & 1.888 \\
3 Jul 2011 & $19: 30: 00$ & 0.015369 & 0.004785 & 55.58 & 1.336 \\
3 Jul 2011 & $20: 00: 00$ & 0.01559 & 0.003884 & 58.81 & 1.380 \\
4 Jul 2011 & $09: 00: 00$ & 0.014992 & 0.003885 & 48.77 & 1.613 \\
4 Jul 2011 & $15: 30: 00$ & 0.015324 & 0.004056 & $\mathbf{6 7 . 5 9}$ & 1.192 \\
Mean & & $\mathbf{0 . 0 1 4 9 8}$ & $\mathbf{0 . 0 0 5 7 5 3}$ & $\mathbf{3 1 . 8 9}$ & $\mathbf{1 . 8 2 0 6 2 7}$ \\
Stdev & & $\mathbf{0 . 0 0 0 3}$ & $\mathbf{0 . 0 0 1 6 8 8}$ & $\mathbf{1 9 . 9 4}$ & $\mathbf{0 . 7 3 3 7 7 9}$ \\
\hline
\end{tabular}

compensate for non-pigmented detritus absorption. For the Lena samples this reduces the uncertainty in the mass specific absorption coefficient from 60 to $34 \%$.

The absorption by TSM increased by a factor of three during the sampling period (Fig. 3, Table 3). The spectral slopes of detritus absorption are listed in Table 3. A decreasing trend of these slopes was observed over the sampling period. Exceptions were seen for stations 3-6, which were located in a tributary branching off from the main Lena stream, the "Kurungnakh arm". All other samples were collected from the main stream and off Samoylov Island (Fig. 1). Slopes of the four Kurungnakh stations are almost twice those of the other samples (Fig. 5). Slopes in the main stream varied from 0.0038 to $0.0062 \mathrm{~nm}^{-1}$, while Kurungnakh station slopes varied between 0.0083 and $0.0089 \mathrm{~nm}^{-1}$.

\subsection{Phytoplankton pigments}

The major pigments, which we found in phytoplankton of the Lena River during our campaign, were chlorophyll $a$, fucoxanthin (fuco), and chlorophyll $b(\mathrm{Chl} b)$. Diadinoxanthin (diadino), alloxanthin (alloxan), zeaxanthin (zeaxan), and lutein were found in lower concentrations at all stations. Some other pigments such as chlorophyll $c 1, c 2(\mathrm{Chl} c 1, c 2)$, neoxanthin (neoxan), and violoxanthin (viola) were not always found and when they were, only at lower concentrations (Fig. 6). Total chlorophyll was calculated by summing

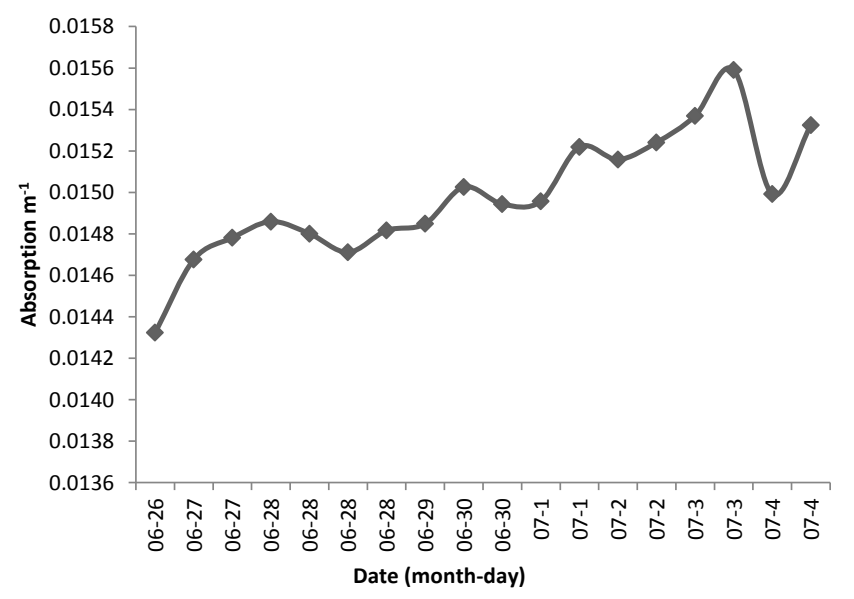

Fig. 4. CDOM semi-logarithmic slopes calculated between 400 and $500 \mathrm{~nm}$ with $442 \mathrm{~nm}$ as reference wavelength using a nonlinear fit.

up chlorophyll $a$ and all of its degradation products. On average the degradation products added $33 \%$ ( $\min 15 \%$, max $50 \%)$ to the total chlorophyll concentration. Relatively high concentrations of fucoxanthin and chlorophyll $b$ indicate that the majority of the species in the Lena River were composed of green algae (Chlorophyta) and diatoms (Bacillariophyta). This was confirmed by the measurements in situ using the BBE multialgal-fluorescence probe. 


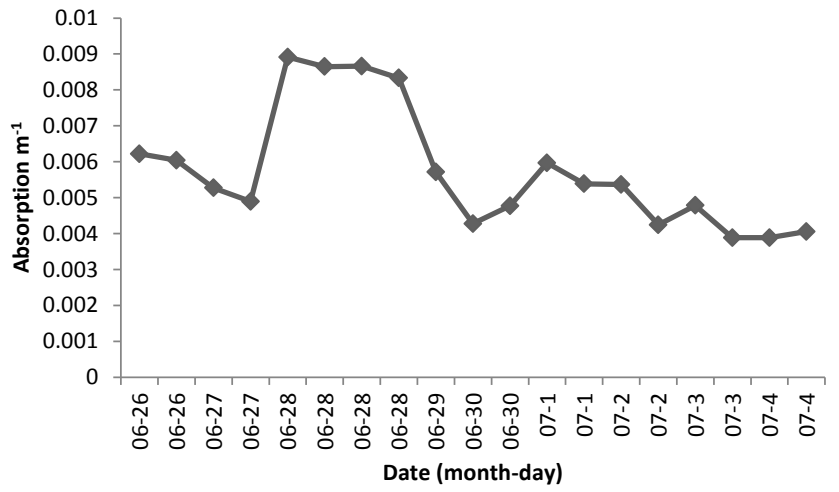

Fig. 5. Detritus semi-logarithmic slopes calculated between 400 and $500 \mathrm{~nm}$ with $442 \mathrm{~nm}$ as reference wavelength using a nonlinear fit.

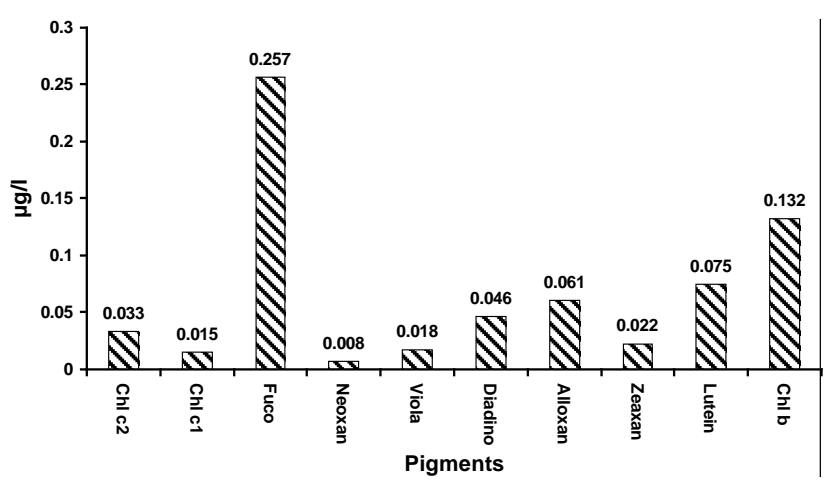

Fig. 6. Mean pigment concentrations, chlorophyll $a$ not included here.

\subsection{Total suspended matter}

Total suspended matter concentration was spatially and temporally variable during the sampling period. Concentrations in samples, which were taken from the Kurungnakh arm (stations 3-6, Fig. 1), were lower than those of the samples of the main channel (Fig. 7). During the observation period concentrations of TSM increased by a factor of four and reached its maximum at the last days of the campaign.

\subsection{Carbon concentrations}

The concentration of DOC was constant over the observation period in June/July at all stations with values of around $9.4 \pm 0.45 \mathrm{~g} \mathrm{~m}^{-3}$ when omitting one value at $16 \mathrm{~g} \mathrm{~m}^{-3}$. These values were double those from samples taken in the second half of August 2011 at the same stations, with values of around $4.6 \pm 0.46 \mathrm{~g} \mathrm{~m}^{-3}(n=38)$, also when omitting one potential erroneous value at $16 \mathrm{~g} \mathrm{~m}^{-3}$ (data not included in the publication).

In contrast, the values of the sum of organic and inorganic particulate carbon (PC) were much more variable. During the campaign in June/July PC values were in the range $0.3-1.9 \mathrm{~g} \mathrm{~m}^{-3}$ with a mean of $0.85 \pm 0.44 \mathrm{~g} \mathrm{~m}^{-3}$, $n=26$. In the second half of August these values were more variable with a range of $0.2-6.0 \mathrm{~g} \mathrm{~m}^{-3}$ and a mean of $1.07 \pm 1.08 \mathrm{~g} \mathrm{~m}^{-3}, n=36$.

\subsection{Beam attenuation and scattering}

The variability of the beam attenuation coefficient $c$ of the Lena River water was determined mainly by the scattering and to less extent by the absorption of TSM, while the CDOM absorption was relatively constant (Fig. 8a, b). Similar to TSM dry weight the beam attenuation coefficient increased by a factor of four during the observation period (Fig. 8b).

The scattering spectrum is given in Fig. 9a. The relationships between the concentrations of TSM and the beam attenuation and absorption coefficients, respectively, show similar scatter.

\subsection{Mass specific inherent optical properties}

The mass specific absorption and scattering coefficients were computed from the slope of the linear regressions between concentrations of chlorophyll, TSM, DOC, and PC and the corresponding absorption and scattering coefficients at $442 \mathrm{~nm}$. The relative uncertainty is calculated from the regression on the logarithm scale to get a mean relative error over the entire range. Due to the limited number of data and the narrow concentration ranges these coefficients have to be regarded as preliminary. For chlorophyll the problem in deriving the absorption coefficients from the minimal difference between the total and the absorption after bleaching, led to a high uncertainty in the concentration specific absorption coefficient.

Pigment absorption:

$$
\begin{aligned}
& \text { a_pig_442 } \quad\left[\mathrm{m}^{-1}\right]=0.128\left[\mathrm{~m}^{2} \mathrm{mg}^{-1}\right] \cdot<\mathrm{Chl} \_a \\
& >\left[\mathrm{mg} \mathrm{m}^{-3}\right], \pm 0.08\left[\mathrm{~m}^{-1}\right], \pm 60 \% \text { relative uncer- } \\
& \text { a_pig_676 } \quad\left[\mathrm{m}^{-1}\right]=0.05\left[\mathrm{~m}^{2} \mathrm{mg}^{-1}\right] \cdot<\mathrm{Chl} a \\
& >\left[\mathrm{mg} \mathrm{m}^{-3}\right] \quad \pm 0.025\left[\mathrm{~m}^{-1}\right], \quad \pm 34 \% \text { relative un- } \\
& \text { certainty. }
\end{aligned}
$$

CDOM absorption:

$$
\begin{aligned}
& \text { a_cdom_442 }\left[\mathrm{m}^{-1}\right]=0.56\left[\mathrm{~m}^{2} \mathrm{~g}^{-1}\right] \cdot<\text { DOC } \\
& >\left[\mathrm{g} \mathrm{m}^{-3}\right] \pm 0.2\left[\mathrm{~m}^{-1}\right], \pm 5 \% \text { relative uncertainty. }
\end{aligned}
$$

When converting $\mu \mathrm{mol}$ DOC into a_cdom_442 the conversion factor is $0.00672\left[\mathrm{~m}^{2} \mu \mathrm{mol}^{-1}\right]$.

Absorption by bleached TSM (detritus):

$$
\begin{aligned}
& \text { a_det_442 }\left[\mathrm{m}^{-1}\right]=0.07\left[\mathrm{~m}^{2} \mathrm{~g}^{-1}\right] \cdot<\mathrm{TSM}>\left[\mathrm{g} \mathrm{m}^{-3}\right] \\
& \pm 0.4\left[\mathrm{~m}^{-1}\right], \pm 42 \% \text { relative uncertainty. }
\end{aligned}
$$

Scattering by particles at $442 \mathrm{~nm}$ derived from a linear regression (Fig. 9c), which has a bias of $1.07 \mathrm{~m}^{-1}$ :

b_tsm_442 $\mathrm{nm}\left[\mathrm{m}^{-1}\right]=0.45\left[\mathrm{~m}^{2} \mathrm{~g}^{-1}\right] \cdot<\mathrm{TSM}>\left[\mathrm{g} \mathrm{m}^{-3}\right]$ $\pm 5.8\left[\mathrm{~m}^{-1}\right], \pm 35 \%$ relative uncertainty. 


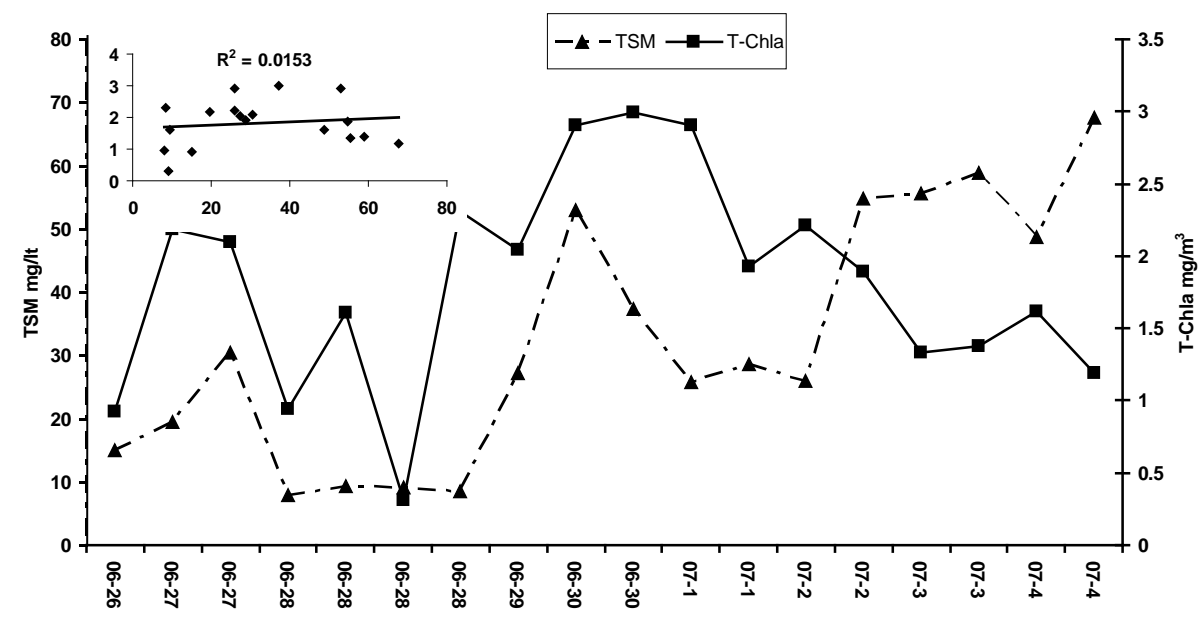

Fig. 7. Fluctuations of chlorophyll $a$ and total suspended matter concentrations. The insert shows the relationship between suspended matter $\left(x\right.$ axis, $\left.\mathrm{g} \mathrm{m}^{-3}\right)$ and chlorophyll $\left(y\right.$ axis, $\left.\mathrm{mg} \mathrm{m}^{-3}\right)$.

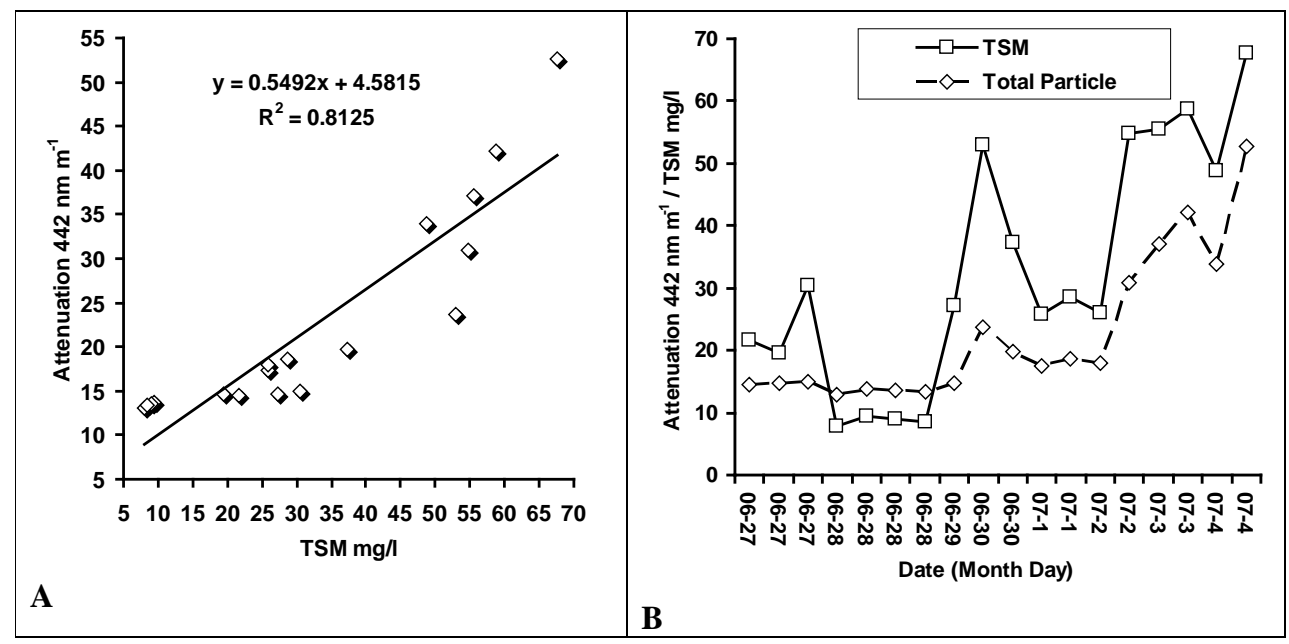

Fig. 8. Co-variation (A) and temporal variations (B) of TSM and the beam attenuation at $442 \mathrm{~nm}$.

Absorption by all particles (TSM) at $442 \mathrm{~nm}$ derived from a linear regression (Fig. 9d), which has a bias of $0.23 \mathrm{~m}^{-1}$ :

$$
\begin{aligned}
& \text { a_tsm_442 } \mathrm{nm} \quad\left[\mathrm{m}^{-1}\right]=0.040\left[\mathrm{~m}^{2} \mathrm{~g}^{-1}\right] \cdot<\mathrm{TSM} \\
& >\left[\mathrm{g} \mathrm{m}^{-3}\right] \pm 0.43\left[\mathrm{~m}^{-1}\right], \pm 31 \% \text { relative uncertainty. }
\end{aligned}
$$

Particulate carbon $\left[\mathrm{g} \mathrm{m}^{-3}\right]$ related absorption coefficient of particulate matter:

$$
\begin{aligned}
& \text { ap_442 } \mathrm{nm}^{-1}\left[\mathrm{~m}^{-1}\right]=0.83\left[\mathrm{~m}^{2} \mathrm{~g}^{-1}\right] \cdot<\mathrm{PC}> \\
& {\left[\mathrm{g} \mathrm{m}^{-3}\right] \pm 0.43\left[\mathrm{~m}^{-1}\right], \pm 37 \% \text { relative uncertainty. }}
\end{aligned}
$$

\section{Discussion}

A major question underpinning our investigations on the biooptical properties of the Lena water is as to how the results compare to other Arctic rivers and estuaries. This leads on to whether a generic bio-optical model can be derived for optical remote sensing of the coastal waters of the Arctic Sea with an eye on other rivers besides the Lena, namely the Yenisei, $\mathrm{Ob}$, and Mackenzie, which also determine the fresh water flux into the Arctic Sea.

Most striking in Lena water is the high concentration of all kinds of humic substances (see also Kattner et al., 1999), defined here as organic degradation products and whereby dissolved and particulate matter are merely defined by the pore size of the filter (see data at http://www.feow.org/ecoregion details.php?eco=608). These dominate the optical properties of all major Arctic estuaries in the form of CDOM and detritus. The DOC concentrations of $\mathrm{Ob}$ and Yenisei, close to their mouths, where river water is not diluted by marine water, is in the range of $5-10 \mathrm{~g} \mathrm{C} \mathrm{m}^{-3}$ with extreme values of $15 \mathrm{~g} \mathrm{C} \mathrm{m}^{-3}$. The concentrations in the Kara Sea, where salinity exceeds $30 \mathrm{ppt}$, is $<1 \mathrm{~g} \mathrm{C} \mathrm{m}^{-3}$ (Korosov et al., 2011), also reported by Hessen et al. (2010). The concentrations, we 


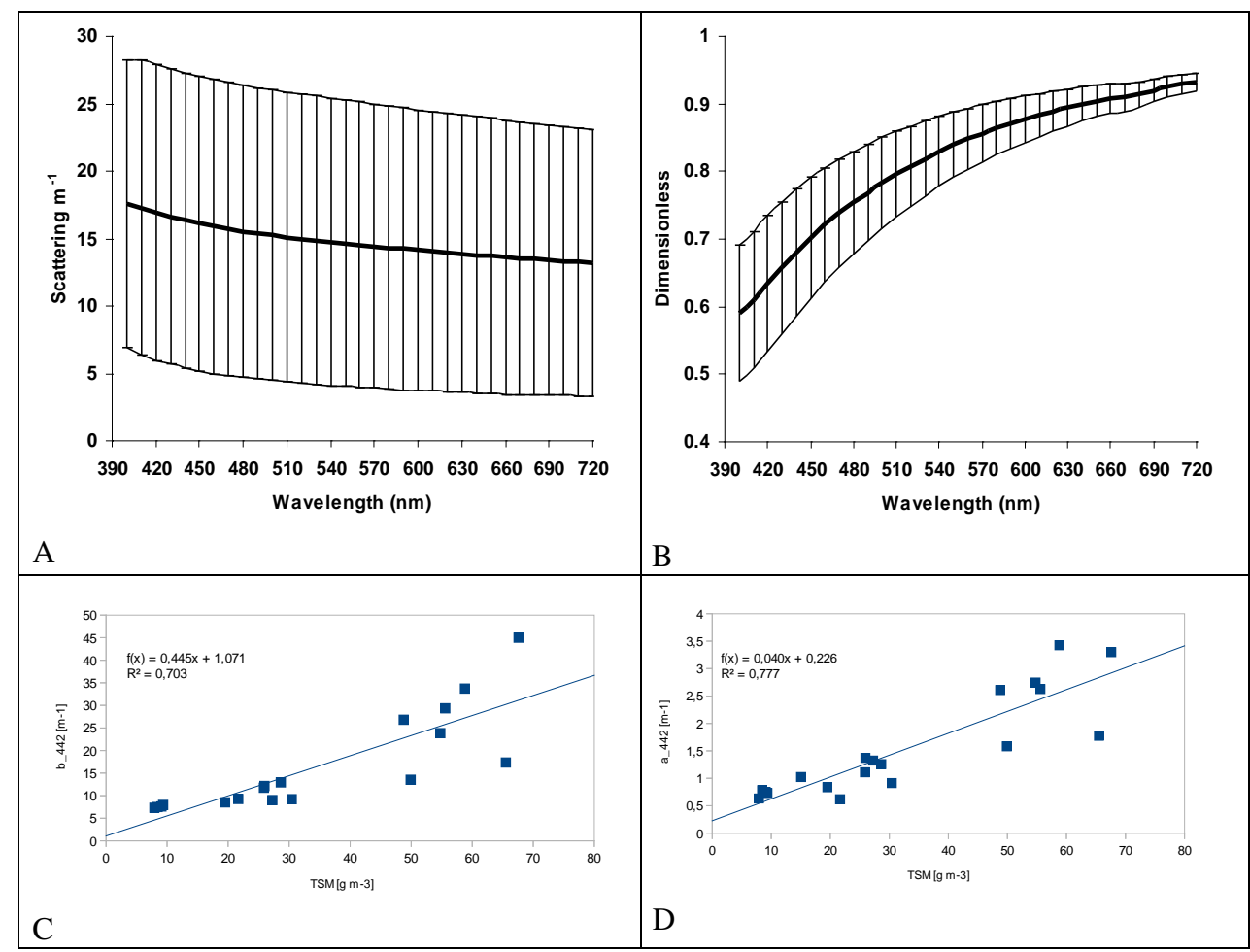

Fig. 9. Means and standard deviations of (A) scattering and (B) the single scatter albedo, as well as the relationship between the total suspended matter concentrations and (C) scattering and (D) absorption coefficients.

found during our campaign in the fresh water region of the Lena were rather constant with a range of $8.5-10.5 \mathrm{~g} \mathrm{C} \mathrm{m}^{-3}$. When including the measurements of August 2011 at the same stations with a mean of $4.6 \pm 0.46 \mathrm{~g} \mathrm{~m}^{-3}$, we found almost the same range of DOC as reported for the $\mathrm{Ob}$ and Yenisei whereby even our extreme values of $16 \mathrm{~g} \mathrm{C} \mathrm{m}^{-3}$ agree. In contrast, the values of the sum of organic and inorganic PC were much more variable. Here one has to consider that also the absorption by minerals may contribute to the overall absorption coefficient of TSM (Estapa et al., 2012). During the campaign in June/July PC values were in the range $0.3-1.9 \mathrm{~g} \mathrm{~m}^{-3}$ with a mean of $0.85 \pm 0.44 \mathrm{~g} \mathrm{~m}^{-3}$, $n=26$. In the second half of August these values were even more variable with a range of $0.2-6.0 \mathrm{~g} \mathrm{~m}^{-3}$ and a mean of $1.07 \pm 1.08 \mathrm{~g} \mathrm{~m}^{-3}, n=36$.

The absorption coefficients of CDOM are easier to compare. In the paper of Hessen et al. (2010) the downwelling irradiance attenuation coefficient $k_{\mathrm{d}}$ is included for some wavelengths in the ultraviolet (UV) spectral range, which are around $10 \mathrm{~m}^{-1}$ for $380 \mathrm{~nm}$ for the $\mathrm{Ob}$ and Yenisei. Since for highly absorbing water, $k_{\mathrm{d}}$ is mainly determined by the absorption coefficient, it can be transferred to an absorption coefficient of $4 \mathrm{~m}^{-1}$ at $442 \mathrm{~nm}$ assuming a spectral slope of 0.015 . For the Lena we found the corresponding coefficient in the range $4-5 \mathrm{~m}^{-1}$.
Absorption coefficients for the Mackenzie Delta (Canada) are reported in Bélanger et al. (2006). Values close to the coast are in the range of $4.5-5.4 \mathrm{~m}^{-1}$ at $330 \mathrm{~nm}$ with a spectral slope of around 0.02. The corresponding values for $442 \mathrm{~nm}$ using this slope would be $0.45-0.55 \mathrm{~m}^{-1}$.

Mean spectral slopes of the absorption coefficients are available for the Great Whale River and Mackenzie River in the Canadian Arctic (Retamal et al., 2007) at 0.016 and $0.0185 \mathrm{~m}^{-1}$, respectively. However, they were derived from the wavelength range $300-650 \mathrm{~nm}$ with a reference wavelength of $320 \mathrm{~nm}$. Slopes derived from the UV spectral range are normally higher (Diehl \& Haardt, 1980), since they are determined by other components of CDOM. Also the spectral slopes in Bélanger et al. (2006) with values in the range of $0.019-0.02 \mathrm{~m}^{-1}$ have obviously been derived from the UV part of the spectrum (but not explicitly mentioned in the paper). Similar CDOM spectral slope values can be found for different coastal and river waters worldwide. Helms et al. (2008) reported values between 0.0158 and $0.0186 \mathrm{~nm}^{-1}$ from the Great Dismal Swamp and the Suwanbnbee River. The mean CDOM spectral slope of Elbe river water is reported to be 0.0188 (Helmholtz Center Geesthacht, unpublished data) or $0.014 \mathrm{~nm}^{-1}$ (Doerffer, 1979). More reports of this parameter can be found in Wozniak and Dera (2007). Slopes of CDOM, which we found for the Lena, are in the range $0.0145-0.0155 \mathrm{~nm}^{-1}$. They were derived from the 
spectral range of $400-500 \mathrm{~nm}$, which is the most relevant part for optical remote sensing.

Variability of the slopes of detritus absorption (range $0.004-0.009 \mathrm{~nm}^{-1}$ ) can be attributed to variations in particle size and/or composition including inorganic particles and content of organic carbon (detritus). Compared to spectra of Estapa et al. (2012) the shape of the spectra of Lena water does not indicate a significant contribution by iron. The spectral slopes are lower compared to mean Baltic and North Sea detritus absorption slopes, which are 0.013 and $0.0116 \mathrm{~nm}^{-1}$, respectively (Babin et al., 2003a). Ferrari et al. (2003) reported values between 0.0095 and $0.0125 \mathrm{~nm}^{-1}$ for the Baltic Sea. These are similar to values found in the NOMAD database (Werdell and Bailey, 2005) which are in the range $0.007-0.015 \mathrm{~m}^{-1}$ (5-95\% percentile).

Concentrations of phytoplankton pigments found are similar to previous studies carried out in the Lena River (Heiskanen and Keck, 1996; Sorokin and Sorokin, 1996). Total chlorophyll $a$ concentration was variable within our sampling period with values between 0.5 and $3 \mathrm{mg} \mathrm{m}^{-3}$. The time series does not show any significant trend during our campaign. The samples taken from the Kurungnakh river arm were not significantly different from the major river. These values match the data of Hessen et al. (2010) for the $\mathrm{Ob}\left(0.4-3.4 \mathrm{mg} \mathrm{m}^{-3}\right)$ and Yenisei $\left(0.6-2.9 \mathrm{mg} \mathrm{m}^{-3}\right)$. Chlorophyll values derived from satellite data are in most cases overestimated due to the difficult separation between CDOM and phytoplankton pigment absorption spectra (Heim et al., this volume). In Hessen et al. (2010) chlorophyll values derived from MODIS satellite data are up to $15 \mathrm{mg} \mathrm{m}^{-3}$ for the Yenisei and up to $8 \mathrm{mg} \mathrm{m}^{-3}$ for the $\mathrm{Ob}$. The chlorophyll values derived from MERIS satellite data (Korosov et al., 2011) are even higher with values up to $30 \mathrm{mg} \mathrm{m}^{-3}$ for the $\mathrm{Ob}$ and Yenisei.

The concentration of TSM was variable in the Lena River and its side arms. We assume that the variability is mainly due to differences in water turbulence, which, however, could only be rated visually. TSM ranged from $10-60 \mathrm{~g} \mathrm{~m}^{-3}$ during the observation period and did not co-vary with the chlorophyll concentration (Fig. 7). Due to the high variability, which depends on local currents, water depth, and river runoff, a direct comparison with corresponding snapshot observations of other Arctic rivers does not help in assessment of these values.

The calculated single scattering albedo of the Lena River was lower in the short and higher in the long wavelength range. This effect is caused by the strong absorption by CDOM at shorter wavelengths (Fig. 9b), which reduces the number of photons to be scattered at these wavelengths. The spectrum of scattering coefficient shows an increase in the short wavelength range and remains flat at longer wavelengths (Fig. 9a). This type of spectral shape is determined by the particle composition and concentration. Especially small lithogenic particles can increase the scattering coefficients

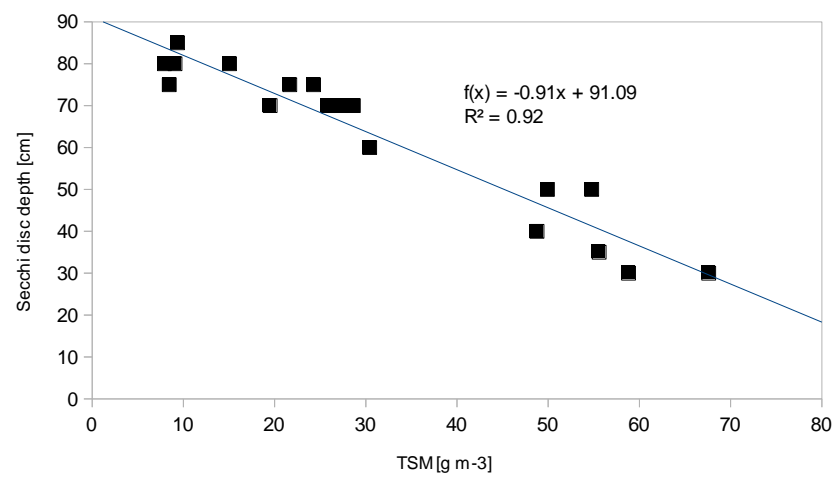

Fig. 10. Relationship between TSM dry weight and the Secchi disc depth for all Lena stations.

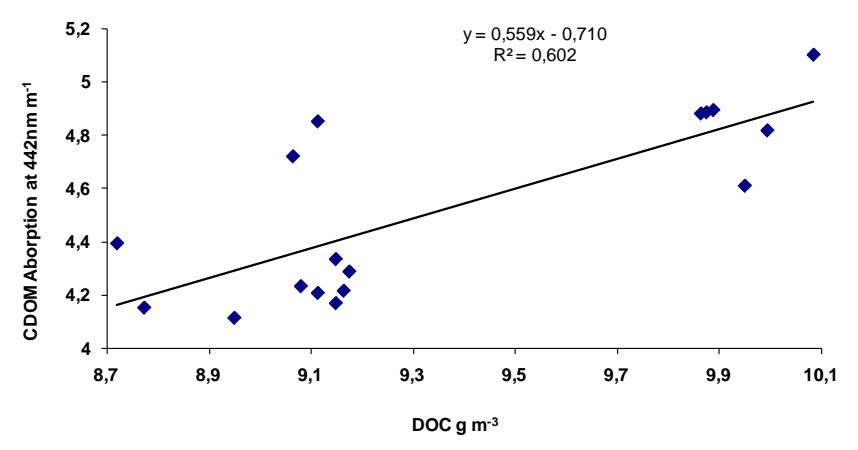

Fig. 11. Relationship between DOC and the absorption coefficient of the filtrate at $442 \mathrm{~nm}$ against pure water as blank.

(Whitmire et al., 2007) and the backscattering ratio (Boss et al., 2004).

The relationship between the beam attenuation and the TSM concentration could be compared with results of Hill et al. (2011), who analyzed the effect of different particle sizes. They found a mean conversion factor of $0.22 \mathrm{~g} \mathrm{~m}^{-2}$ with a range between 0.2 and 0.4 for a wavelength of $670 \mathrm{~nm}$. For the Lena water we found a corresponding factor (for $670 \mathrm{~nm}$ ) of $0.37 \mathrm{~g} \mathrm{~m}^{-2}$ (see Figs. 8a and 2d).

The relationship between the TSM dry weight and the scattering coefficient of TSM shows a clear linear relationship (Fig. 9c) when we omit the measurements of the first day. The mass specific scattering coefficient is $0.45 \mathrm{~m}^{2} \mathrm{~g}^{-1} \pm 35 \%$. Babin et al. (2003b) found average values of 1.0 and $0.5 \mathrm{~m}^{2} \mathrm{~g}^{-1}$ in optical case 1 and case 2 waters, respectively, of the North Sea and Baltic Sea. The scatter diagram of TSM concentration and the detritus absorption at $442 \mathrm{~nm}$ (Fig. 12) shows a logarithmic relationship, which might be due to changes in the composition of TSM at different concentration levels.

For the mass specific absorption coefficient of TSM of samples from coastal Louisiana and the Mississippi and Atchafalaya Rivers, Estapa et al. (2012) found values between 0.01 and $0.05 \mathrm{~m}^{2} \mathrm{~g}^{-1}$ at $550 \mathrm{~nm}$. For the 


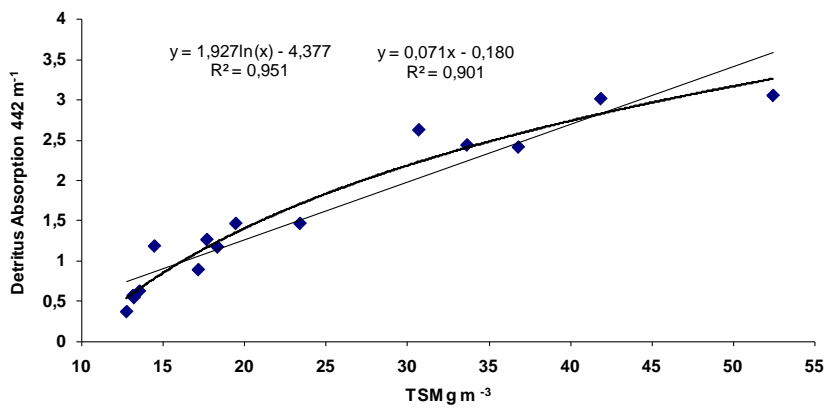

Fig. 12. Relationship between total suspended matter dry weight (TSM) and the absorption coefficient of the particulate matter at $442 \mathrm{~nm}$, logarithmic and linear fit.

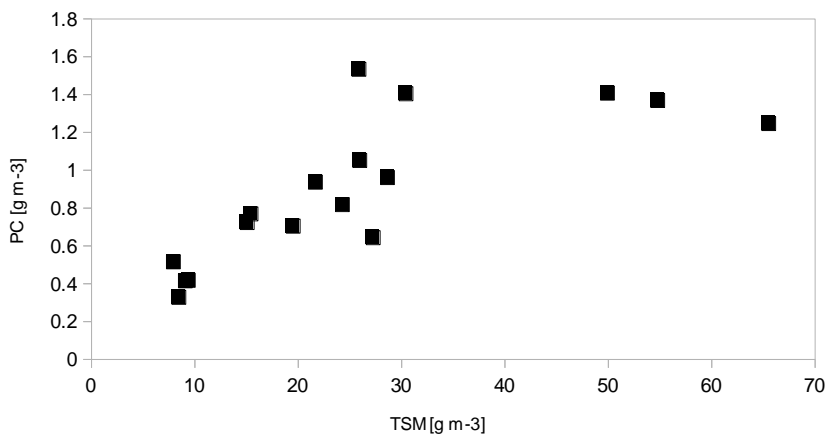

Fig. 13. Relationship between particulate carbon and total suspended matter concentration.

Lena the corresponding specific absorption coefficient is $0.027 \mathrm{~m}^{2} \mathrm{~g}^{-1} \pm 31 \%$ at $550 \mathrm{~nm}$.

A high correlation was also found for the relationship between TSM dry weight and the Secchi disc depth (Fig. 10). CDOM contributes also to the light penetration, but since its concentration was rather constant during the observation period, the variability in the Secchi disc depth was mainly determined by suspended particles.

Of further interest was the relationship between particulate organic carbon and TSM, which is shown in Figs. 13 and 14. These figures show that the three samples with very high concentrations of TSM have lower amount of PC, since they presumably consist mainly of mineral suspended matter.

Due to the dominating effect of absorption mainly by organic particulate matter and the low chlorophyll concentration, it was difficult to derive the specific phytoplankton pigment absorption coefficient using the filter pad and bleaching method. The relationship between chlorophyll $a$ and the pigment absorption coefficient at $442 \mathrm{~nm}$ was: $<$ Chl_ $a>\left[\mathrm{mg} \mathrm{m}^{-3}\right]=7.8\left[\mathrm{~m}^{2} \mathrm{mg}^{-1}\right] \cdot$ apig_4 $442 \mathrm{~nm}\left[\mathrm{~m}^{-1}\right]$, which is a lower conversion factor than normally found for open and coastal water phytoplankton.

The relationship between DOC and the absorption by CDOM at $442 \mathrm{~nm}$ (Fig. 11) were compared to measurements in the Baltic Sea. Ferrari et al. (1996) found mean values be-

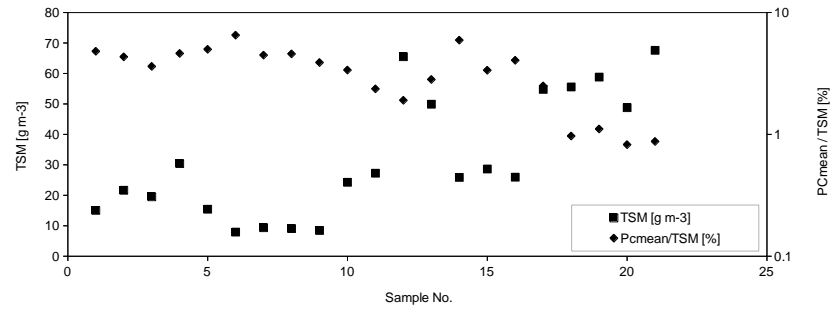

Fig. 14. Total suspended matter dry weight (TSM) in $\mathrm{g} \mathrm{m}^{-3}$ and the $\mathrm{PC}$ content as \% of TSM, in sequence of sample number.

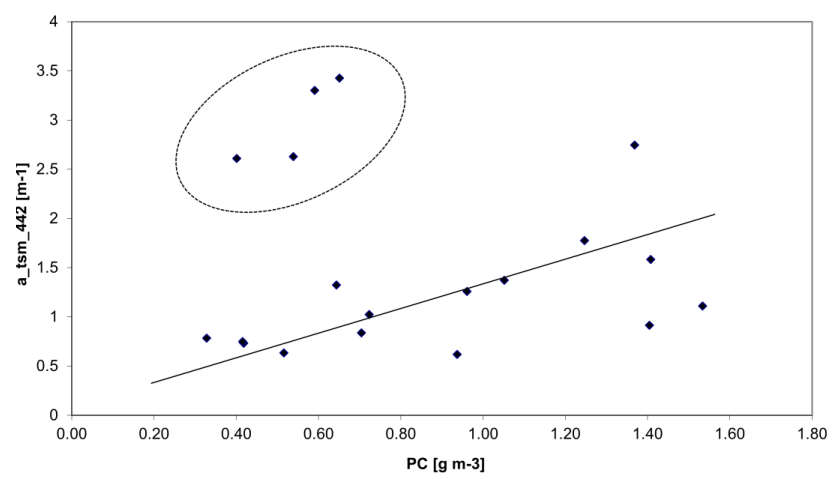

Fig. 15. Relationship between $P C$ and the absorption coefficient of particulate matter at $442 \mathrm{~nm}$, data points within the circle are only from samples of 3 and 4 July 2011, when omitting these points the regression is a_TSM_442 $<\mathrm{m}^{-1}>=0.83<\mathrm{m}^{2} \mathrm{~g}^{-1}>\cdot \mathrm{PC}<\mathrm{g} \mathrm{m}^{-3}>$ $+0.26<\mathrm{m}^{-1}>$.

tween 49 and $73 \mathrm{~m}^{2} \mu \mathrm{mol}^{-1}$ for $355 \mathrm{~nm}$, which depend on the DOC analysis technique (see their Table 6). When we convert our values to a wavelength of $355 \mathrm{~nm}$ using a spectral slope of $0.014 \mathrm{~m}^{-1}$, we get a conversion factor of $44 \mathrm{~m}^{2} \mu \mathrm{mol}^{-1}$. Fichot and Benner (2011) measured the absorption at 275 and $295 \mathrm{~nm}$ in the northern Gulf of Mexico and Beaufort Sea. For their conversion from CDOM absorption to DOC on the log scale they used the absorption at both wavelengths: $\log (\mathrm{DOC})=a+b \cdot \log (\operatorname{ag} 275)+c \cdot \log (\operatorname{ag} 295)$. The conversion factors for the concentration range ag_275 $>3.5 \mathrm{~m}^{-1}$ were $a=2.9, b=2.77$, and $c=-2.04$ for the northern Gulf of Mexico and $a=2.36, b=3.04$, and $c=-2.13$ for the Beaufort Sea. When we transfer our values to a wavelength of $285 \mathrm{~nm}$ using again a spectral slope of $0.014 \mathrm{~m}^{-1}$ we get corresponding conversion factors for the log scale $\log (\mathrm{DOC})=a+b \cdot \log (\mathrm{ag} 285)$ of $a=4.73$ and $b=0.52$ with an uncertainty of $\pm 3 \%$ on the logarithmic scale.

\section{Summary and conclusions}

The primary goal of this investigation was to determine the bio-optical properties of Lena River water during the phase of maximum runoff in order to obtain a basis for optical 
remote sensing and primary production studies. The investigation site, where we expected maximum concentrations, was the entrance of the Lena Delta before the water enters the coast of the Laptev Sea. The measured variables include absorption and scattering coefficients of water samples before and after filtration to separate the particulate from the dissolved fraction of water constituents. The absorption by particulate matter was further split into the absorption coefficients of phytoplankton pigments and detritus. Also the concentrations of total suspended matter dry weight and of phytoplankton pigments were determined.

Although the short investigation period could provide us with only a snapshot of Lena River optical properties, it was the first time that crucial bio-optical properties of the Lena River were studied during the most dynamic period when the flow and material transport are at a maximum. Furthermore, the data were already important for the evaluation of satellite data (Heim et al., this volume).

Most remarkable was the extremely high absorption of light by the dissolved and particulate fraction of humic substances. Secchi disc depths (SD) showed a maximum of about $90 \mathrm{~cm}$. According to our visual inspection of the water and the regression (Fig. 10) we have to attribute this maximum SD to the dissolved organic matter fraction. This depth was then reduced to $30 \mathrm{~cm}$ by variable concentrations of TSM in the range of $8-70 \mathrm{~g} \mathrm{~m}^{-3}$ with a linear relationship between TSM and SD. However, for this phase of maximum river runoff we expected higher TSM concentrations compared to late summer conditions with low water. Visual turbidity observations in August 2008 in the same area and also satellite data of summer periods indicate much higher TSM concentrations than during this campaign.

The linear relationship between DOC and the CDOM absorption at $442 \mathrm{~nm}$ allows the determination of DOC also from optical remote sensing data, from which CDOM absorption can be determined (see Heim et al., this volume). More difficult is the determination of PC from optical data, since the scattering as well as the absorption coefficient is also determined by particulate matter without carbon.

With respect to the light climate, which is determined by the extremely high absorption in the blue spectral range, the chlorophyll concentration of $1-4 \mathrm{mg} \mathrm{m}^{-3}$ was relatively high. Since the water depth of the Lena at the sampling stations was around $6 \mathrm{~m}$ with a range of 4-21 $\mathrm{m}$, the question that arises is how phytoplankton can develop under these poor light conditions.

Of interest for remote sensing applications are the spectral slopes of the absorption coefficients of organic matter. The mean value of about $0.015 \mathrm{~m}^{-1}$ corresponds to what was found in many other estuaries, e.g., the river Elbe. The slight but clear trend over our observation period is presumably due to changes in the composition of organic matter with the river runoff. This corresponds to an increase of the absorption by TSM and a decrease of the absorption by dissolved organic matter. Thus, for remote sensing algorithms it might be important to introduce not only one spectral slope but two, which bracket the mean minimum and maximum values.

Since the organic matter dominates the absorption of Lena water, it will be difficult to identify phytoplankton from reflectance measurements, since its absorption contributes less than $10 \%$ to the overall absorption. Due to the high absorption by CDOM in the blue part of the spectrum the sunlightinduced fluorescence of chlorophyll will also be low and thus difficult to determine from reflectance spectra.

Although we have sampled at only a few locations and for a short period we expect no significant differences at other locations in the Lena Delta during this time, since the environmental conditions elsewhere were very similar, as indicated also by satellite data (Heim et al., this volume).

It was possible to establish a preliminary bio-optical model of the Lena water, which can be used for optical remote sensing. This model links the concentration of different water constituents with their optical properties. Where a comparison with other areas was possible, in particular with the $\mathrm{Ob}$ and Yenisei, the values of Lena were found to be similar. The concentration range of phytoplankton and CDOM was small, which limits the general application of the results. However, since our observation period was during the phase with the maximum runoff, the data can be used for estimating the input of substances from the Lena into the coastal water of the Laptev Sea and related to remote sensing data.

\section{Appendix A}

Our present bio-optical model for the Lena water consists of four components: (1) absorption by phytoplankton pigments, (2) absorption by CDOM, (3) absorption by bleached total suspended matter (detritus), and (4) scattering by TSM, all defined for $442 \mathrm{~nm}$.

The mean ranges and conversion factors are the following. Range of chlorophyll: $0.0-10 \mathrm{mg} \mathrm{m}^{-3}$

Conversion to absorption by pigments at $442 \mathrm{~nm}$ :

$$
\begin{aligned}
& \text { a_pig_442 }\left[\mathrm{m}^{-1}\right]=0.128\left[\mathrm{mg}^{-1} \mathrm{~m}^{2}\right] \cdot<\mathrm{Chl} \_a> \\
& {\left[\mathrm{mg} \mathrm{m}^{-3}\right] .}
\end{aligned}
$$

Absorption by CDOM at $442 \mathrm{~nm}$ range: up to $5 \mathrm{~m}^{-1}$ Spectral slope of CDOM: $0.015 \mathrm{~m}^{-1}$

Relationship between DOC $\left[\mathrm{g} \mathrm{m}^{-3}\right]$ and absorption coefficient of CDOM:

$$
\begin{aligned}
& \text { a_cdom_442 } \mathrm{nm}\left[\mathrm{m}^{-1}\right]=0.56\left[\mathrm{~g}^{-1} \mathrm{~m}^{2}\right] \cdot<\text { DOC }> \\
& {\left[\mathrm{g} \mathrm{m}^{-3}\right] .}
\end{aligned}
$$

Absorption by bleached TSM range: up to $5 \mathrm{~m}^{-1}$

Spectral slope of bleached TSM absorption spectrum: $0.006 \mathrm{~m}^{-1}$

Conversion: absorption by bleached TSM as

$$
\begin{aligned}
& \text { a_det_442 }\left[\mathrm{m}^{-1}\right]=0.07\left[\mathrm{~g}^{-1} \mathrm{~m}^{2}\right] \cdot<\mathrm{TSM}>\left[\mathrm{g} \mathrm{m}^{-3}\right] . \\
& \text { Scattering by particles b_tsm_442 range: } 5-50 \mathrm{~m}^{-1}
\end{aligned}
$$


Conversion: scattering by particles as

$$
\begin{aligned}
& \text { b_tsm_442 } \mathrm{nm}\left[\mathrm{m}^{-1}\right]=0.45\left[\mathrm{~g}^{-1} \mathrm{~m}^{2}\right] \cdot<\mathrm{TSM}> \\
& {\left[\mathrm{g} \mathrm{m}^{-3}\right] .}
\end{aligned}
$$

Conversion: particulate carbon $\left[\mathrm{g} \mathrm{m}^{-3}\right]$ and absorption coefficient of bleached TSM (detritus) as

$$
\begin{aligned}
& \text { a_det_442 nm } \quad\left[\mathrm{m}^{-1}\right]=0.83\left[\mathrm{~g}^{-1} \quad \mathrm{~m}^{2}\right] \cdot<\mathrm{PC}> \\
& {\left[\mathrm{g} \mathrm{m}^{-3}\right] .}
\end{aligned}
$$

Acknowledgements. We are thankful to Günter Stoof and Waldemar Schneider, both at the Alfred Wegener Institute for Polar and Marine Research, who organized the boat trips and all the logistics in the Samoylov Station. We also thank Kerstin Heymann and Kristine Carstens for helping the pre-cruise preparation and analyzing the HPLC data, and to Bettina Oppermann, Julia Haafke and Saskia Ohse for help with the sampling and analyzing of the carbon samples. The research work was supported by the PACES Program of HZG and AWI as well as the ENMAP research program of DLR and the Coastcolour Project of the ESA. Finally we thank the reviewers for their valuable advice, which helped us to improve the manuscript significantly.

The service charges for this open access publication have been covered by a Research Centre of the Helmholtz Association.

Edited by: P. Overduin

\section{References}

Babin, M., Stramski, D., Ferrari, G. M., Claustre, H., Bricaud, A., Obolensky, G., and Hoepffner, N.: Variations in the light absorption coefficients of phytoplankton, nonalgal particles, and dissolved organic matter in coastal waters around Europe, J. Geophys. Res., 108, 3211, doi:10.1029/2001JC000882, 2003a.

Babin, M., Morel A, Fournier-Sicre, V., Fell, F., and Stramski, D.: Light scattering properties of marine particles in coastal and open ocean waters as related to the particle mass concentration, Limnol. Oceanogr., 48, 843-859, 2003 b.

Bélanger, S., Xie, H., Krotkov, N., Larouche, P., Vincent, W. F., and Babin, M.: Photomineralization of terrigenous dissolved organic matter in Arctic coastal waters from 1979 to 2003: Interannual variability and implications of climate change, Global Biogeochem. Cy., 20, GB4005, doi:10.1029/2006GB002708, 2006.

Beutler, M., Wiltshire, K. H., Meyer, B., Moldaenke, C., Luring, C., Meyerhofer, M., Hansen, U. P., and Dau, H.: A fluorometric method for the differentiation of algal populations in vivo and in situ, Photosynth. Res., 72, 39-53, 2002.

Boss E., Pegau, W. S., Lee, M., Twardowski, M., Shybanov, E., Korotaev, G. and Baratange, F.: Particulate backscattering ratio at LEO 15 and its use to study particle composition and distribution, J. Geophys. Res., 109, C01014, doi:10.1029/2002JC001514, 2004.

Boss E., Slade, W. H., Behrenfeld , M., and Dall'Olmo, G.: Acceptance angle effects on the beam attenuation in the ocean, Vol. 17, No. 3., Optics Express, 2 February 2009.
Cauwet, G. and Sidorov, I.: The biogeochemistry of Lena River: organic carbon and nutrients distribution, Mar. Chem., 53, $211-$ 227, 1996.

Diehl, P. and Haardt, H.: Measurement of the spectral attenuation to support biological research in a plankton tube experiment, Oceanol. Acta, 3, 89-96, 1980.

Dmitrenko I. A., Sergey, A., Kirillov, L., and Tremblay, B.: The long-term and interannual variability of summer fresh water storage over the eastern Siberian shelf: Implication for climatic change, J. Geophys. Res., 113, C03007, doi:10.1029/2007JC004304, 2008.

Doerffer, R.: Untersuchung über die Verteilung oberflächennaher Substanzen im Elbe-Aestuar mit Hilfe von Fernmessverfahren, Arch. Hydrobiol./Suppl., 43, 119-224, 1979.

Estapa, M. L., Boss, E., Mayer, L. M., and Roesler, C. S.: Role of iron and organic carbon in mass-specific light absorption by particulate matter from Louisiana coastal waters, Limnol. Oceanogr., 57, 97-112, 2012.

Ferrari, G. M., Franco, G. B., and Babin, M..: Geo-chemical and optical characterizations of suspended matter in European coastal waters, Estuar. Coast. Shelf S., 57, 17-24, 2003.

Fichot, D. G. and Benner, R.: A novel method to estimate DOC concentrations from CDOM absorption coefficients in coastal waters, Geophys. Res. Lett., 38, L03610, doi:10.1029/2010GL046152, 2011

Gueguen, C., Guo, L., and Tanaka, N.: Distributions and characteristics of colored dissolved organic matter in the Western Arctic Ocean, Cont. Shelf Res., 25, 1195-1207, 2005.

Heim, B., Abramova, E., Doerffer, R., Günther, F., Hölemann, J., Kraberg, A., Lantuit, H., Loginova, A., Martynov, F., Overduin, P. P., and Wegner, C.: Ocean Colour remote sensing in the Southern Laptev Sea: evaluation and applications, Biogeosciences Discuss., 10, 3849-3889, doi:10.5194/bgd-10-3849-2013, 2013.

Heiskanen, A. S. and Keck, A.: Distribution and sinking rates of phytoplankton, detritus, and particulate biogenic silica in the Laptev Sea and Lena River. Arctic (Siberia), Mar. Chem., 53, 229-245, 1996.

Helms, J., Stubbins, A., Ritchie, J., D., Minor, E., Kieber, D., and Mopper, K.: Absorption spectral slopes and slope ratios as indicators of molecular weight, source, and photo-bleaching of chromophoric dissolved organic matter, Limnol. Oceanogr., 53, 955969, 2008.

Hessen, D., Carroll, J.-L., Kjeldstad, B., Korosov, A., Pettersson, L., Pozdnyakov, D., and Sørensen, K.: Input of organic carbon as determinant of nutrient fluxes, light climate and productivity in the $\mathrm{Ob}$ and Yenisey estuaries, Estuar. Coast. Shelf S., 88, 53-62, 2010.

Hill, P. S., Boss, E., Newgard, J. P.,Law, B. A., and Milligan, T. G.: Observations of the sensitivity of beam attenuation to particle size in a coastal bottom boundary layer, J. Geophys. Res., 116, C02023, doi:10.1029/2010JC006539, 2011.

Jerlov, N. G.: A Transparency Meter for Ocean Water, Tellus IX, 2, 1957.

Kattner, G., Lobbes, J. M., Fitznar, H. P., Engbrod, R., Nötthig, E.M., and Lara, R. J.: Tracing dissolved organic substances and nutrients from the Lena River through Laptev Sea (Arctic), Mar. Chem., 65, 25-39, 1999.

Korosov, A., Pozdnyakov, D., and Grassl, H.: Spaceborne quantitative assessment of dissolved organic carbon 
fluxes in the Kara Sea, Adv. Space Res., 50, 1173-1188, doi:10.1016/j.asr.2011.10.008, 2012.

Lara, R. J., Rachold, V., Kattner, G., Hubberten, H. W., Guggenberger, G., Skoog, A. N., and Thomas, N. D.: Dissolved organic matter and nutrients in the Lena River, Siberian Arctic: Characteristics and distribution, Mar. Chem., 59, 301-309, 1998.

Lobbes J. M., Fitznar, H. P., and Kattner, G.: Biogeochemical characteristics of dissolved and particulate organic matter in Russian rivers entering the Arctic Ocean, Geochim. Cosmochim. Ac., 64, 2973-2983, 2000.

McClelland, J. W., Déry, S. J., Peterson, B. J., Holmes, R. M., and Wood, E. F.: A pan-arctic evaluation of changes in river discharge during the latter half of the 20th century, Geophys. Res. Lett., 33, L06715, doi:10.1029/2006GL025753, 2006.

Mitchell B. G, Bricaud, A., Carder, K., Cleveland, J., Ferrari, G., Gould, R., Kahru, M., Kishino, M., Maske, M. H., Moisan, T., Moore, L., Nelson, N., Phinney, D., Reynolds, R., Sosik, H., Stramski, D., Tassan, S., Trees, C., Weidemann, A., Wieland, J., and Vodacek, A.: "Determination of spectral absorption coefficients of particles, dissolved material and phytoplankton for discrete water samples", in: Ocean Optics Protocols for Satellite Ocean Color Sensor Validation, Revision 2, edited by: Fargion, G. S. and Mueller J. L., NASA/TM-209966, NASA Goddard Space Flight Center, Greenbelt, Md., 125-153, 2000.

Morison J., Kwok, R., Peralta, F. C., Alkire, M., Rigor, I., Andersen, R., and Steele, M.: Changing Arctic Ocean freshwater pathways, Nature, 481, 66-70, doi:10.1038/nature10705, 2012.

Payette, S., Delwaide, A., Caccianiga, M., and Beauchemin M.: Accelerated thawing of subarctic peatland permafrost over the last 50 years, Geophys. Res. Lett., 31, L18208, doi:10.1029/2004GL020358, 2004.

Pozdnyakov, D., Korosov, A., Pettersson, L., and Johannessen, O.: MODIS evidences the river run-off impact on the Kara Sea trophy, Int. J. Remote Sens., 26, 3641-3648, 2005.

Rachold, V., Alabyan, A., Hubberten, H.-W., Korotaev, V. N., and Zaitsev, A. A.: Sediment transport to the Laptev Sea - Hydrology and geochemistry of the Lena River, Polar Res., 15, 183-196, 1996.
Retamal, L., Vincent, W. F., Martineau, C., and Osburn, C. L.: Comparison of the optical properties of dissolved organic matter in two river-influenced coastal regions of the Canadian Arctic, Estuar. Coast. Shelf S., 72, 261-272, 2007.

Röttgers, R. and Gehnke S.: Measurement of light absorption by aquatic particles: improvement of the quantitative filter technique by use of an integrating sphere approach, Appl. Optics, 51, 1336$1351,2012$.

Sorokin, Y. I. and Sorokin, P. Y.: Plankton and Primary Production in the Lena River Estuary and in the South-eastern Laptev Sea, Estuar. Coast. Shelf S., 43, 399-418, 1996.

Stedmon, C., Amon, R., Rinehart, A., and Walker, S.: The supply and characteristics of colored dissolved organic matter (CDOM) in the Arctic Ocean: Pan Arctic trends and differences, Mar. Chem., 124, 108-118, 2011.

Sullivan, J. M., Michael, S. T., Zaneveld, J. R. V., Moore, C. M., Barnard, A. H., Donaghay, P. L., and Rhoades, B.: Hyperspectral temperature and salt dependencies of absorption by water and heavy water in the 400-750 nm spectral range, Appl. Optics, 45, 5294-5309, 2006.

Walsh, J. E.: Arctic as a bellwether, Nature, 352, 19-20, 1991.

Werdell, P. J. and Bailey, S. W.: An improved in-situ bio-optical data set for ocean color algorithm development and satellite data product validation, Remote Sens. Environ., 98, 122-140, 2005.

Whitmire A. L., Boss, E., Cowles, T. J., and Pegau, W. S.: Spectral variability of the particulate backscattering ratio, Optics Express, 15, 7019-7031, 2007.

Wozniak B. and Dera J.: Light Absorption in Sea Water. Atmospheric and Oceanographic Sciences Library 33. Springer Science and Business Media LLC, 2007.

Zaneveld J. R. V., Kitchen, J. C., and Moore, C.: The Scattering Error Corection of Reflecting-Tube Absorption Meters, SPIE Vol 2258 Ocean Optics XII, 1994.

Zapata, M., Rodriguez, F., and Garrido, J. L.: Separation of chlorophylls and carotenoids from marine phytoplankton: a new HPLC method using a reversed phase C8 column and pyridinecontaining mobile phases, Mar. Ecol.-Prog. Ser. 195, 29-45, 2000. 